\title{
A PM-Assisted Synchronous Reluctance Motor with Two Slot-Pitch Winding
}

\author{
Shaohong Zhu, Tom Cox, Zeyuan Xu and Chris Gerada \\ Power Electronics, Machines and Control Research Group, University of Nottingham, Nottingham, UK
}

\begin{abstract}
This paper presents a novel electric motor solution to tackle the increasing demand on the traction motor for electric vehicles. The proposed electric motor has a 24 slots 10 poles fractional slot distributed winding and a PM-assisted synchronous reluctance (PMaSynR) rotor with arc-shaped barriers. First, the winding layout will be introduced. Then, a comparison with other winding layouts will be detailed. The benefits of the proposed solution including low torque ripple and high reluctance torque capability will be demonstrated. All this confirms that it is a good trade-off solution for traction application.
\end{abstract}

Index Terms - electric vehicle, fractional slot distributed winding, PM-assisted synchronous reluctance motor

\section{INTRODUCTION}

The electric motor is a key enabling technique in transportation electrification applications such as electric vehicles (EVs) or more electric aircraft [1]. These applications demand extremely good power/torque density, high efficiency, wide speed constant power operation and manufacturability of the electric motor as these factors will affect the range, cost and energy efficiency of the vehicle [1].

Several technology advancements in the areas of electric motor topology, high-performance steel, winding topology, and novel permanent magnet (PM), have made to improve the torque density, efficiency, and reduce costs in both manufacturing and operation [2]-[4].

Of the electric motor topologies, the induction motor and switched reluctance motor tend to be a robust and cheap solution due to their simple mechanical structure and magnet-free design. However, they suffer lower torque density, poor power factor and efficiency when compared with permanent-magnet (PM) synchronous motors [2]. Thus, the PM brushless motor is preferred in the current electric vehicle market [5].

Among the more demanding challenges for PM brushless motors designed for EV traction applications are the reluctance torque contribution, torque ripple, resistance to demagnetization, and manufacturability [1]. In this paper, a PM synchronous reluctance (SynR) motor (SynRM) associated with a novel 24 slots 10 poles $(24 \mathrm{~S}$ 10P) fractional slot distributed winding is proposed to tackle these challenges. The $24 \mathrm{~S}-10 \mathrm{P}$ configuration was proposed for a surface-mounted permanent magnet motor in [6], which was derived from the conventional 12 slots 10 poles $(12 \mathrm{~S}-10 \mathrm{P})$ fractional slot concentrated winding (FSCW) motor. The comparative studies of the $24 \mathrm{~S}-10 \mathrm{P}$

This work is funded by the INNOVATIVE doctoral programme, which is partially funded by the Marie Curie Initial Training Networks with conventional $12 \mathrm{~S}-10 \mathrm{P}$ and 90 slots 10 poles (90S$10 \mathrm{P})$ were studied in [7], which suggests its advantages in terms of torque density and losses. However, the advantages in the torque ripple and reluctance torque contribution were not fully explored. In addition, the principle and inherent reason behind these advantages were not elaborated.

In this paper, the characteristics of the 24S-10P fractional slot distribution winding (FSDW) will be introduced and compared with other winding topologies with the same pole number. Then, the impact of winding topology and rotor design on the torque capability with focus on the reluctance torque and torque ripple will be revealed. Finally, to evaluate the performance expectations, a PM-assisted synchronous reluctance motor (PMaSynRM) with the 24S-10P winding layout and three other different winding topologies with the same rotor will be designed and compared.

\section{DESIGN CONSIDERATIONS}

\section{A. Reluctance Torque}

The EM torque generated by the PM synchronous motor includes two components: magnet torque and reluctance torque. The torque equation is as below

$$
\begin{gathered}
T_{\text {em }}=T_{\text {magnet }}+T_{\text {rel }} \\
T_{\text {magnet }}=\frac{m}{2} P \psi_{p m} i_{q} \\
T_{\text {rel }}=\frac{m}{2} P\left(L_{d}-L_{q}\right) i_{d} i_{q}
\end{gathered}
$$

As can be seen, the magnet torque $T_{\text {magnet }}$ is related to magnet flux linkage $\psi_{p m}$, while the reluctance torque $T_{r e l}$ is determined by difference between $L_{\mathrm{d}}$ and $L_{\mathrm{q}}$.

In general, if ignoring the high order winding inductance, the self- and mutual- inductance of a threephase winding can be expressed [8][9]

$$
\begin{gathered}
L_{x x}=L_{0}+L_{2} \cos 2 P \theta_{r} \\
M_{x y}=M_{0}+M_{2} \cos \left(2 P \theta_{r}-\frac{2 \pi}{3}\right)
\end{gathered}
$$

where $L_{0}$ and $M_{0}$ are the average value of respective inductance components; $L_{2}$ and $M_{2}$ are the amplitude of cosine function of the inductance variation, 
respectively. $\theta_{r}$ is the space angle of phase winding; subscript $x$ and $y$ denote the winding phase considered.

From winding function theory [8], the $L_{2}$ and $M_{2}$ is related to the rotor airgap length function, namely rotor saliency function in relation to $\theta_{r}$.

After $d$ - $q$ transformation, the $d$ - and $q$ - inductance can be achieved as [9]

$$
\begin{aligned}
& L_{d}=\left(L_{0}-M_{0}\right)+\left(\frac{L_{2}}{2}+M_{2}\right) \\
& L_{q}=\left(L_{0}-M_{0}\right)-\left(\frac{L_{2}}{2}+M_{2}\right)
\end{aligned}
$$

Thus, the reluctance torque may be written as

$$
\begin{gathered}
T_{e m}=\frac{m}{2} P L_{\text {diff }} i_{d} i_{q} \\
L_{\text {diff }}=L_{2}+2 M_{2}
\end{gathered}
$$

Therefore, to improve the reluctance torque contribution, the mutual coupling between windings, particularly $M_{2}$, plays a critical role in generating reluctance torque. That is the reason why the PMaSynRM with ISDW configuration can normally generate considerable reluctance torque compared to the same SynR rotor with FSCW configuration as FSCW configuration normally has no or very low mutual coupling between phases [10].

\section{B. Torque Ripple}

Based on the on the Lorentz force law, the instantaneous torque can be expressed as [11]

$$
\begin{gathered}
T_{e m 1}=T_{a v g}+T_{\text {ripple }} \\
T_{\text {avg }}=\frac{\mu_{0}}{g} r l \pi P f_{s, v} f_{r, v} \sin \gamma_{d} \\
T_{\text {ripple }}=-\frac{\mu_{0}}{g} r l \pi P \sum_{\substack{v=(6 k+1) P \\
k=1,2,3 \ldots}} v f_{s, v} f_{r, v} \sin \left((v \pm P) w_{r} t\right. \\
\left. \pm \gamma_{d}\right)
\end{gathered}
$$

where $r$ and $l$ is the rotor radius and stack length, respectively; $\gamma_{d}$ is the current phase advance angle; $f_{s, v}$ and $f_{r, v}$ are the amplitude of $v^{\text {th }}$-order stator and rotor MMF harmonic, respectively.

It can be observed that harmonic orders of the ripple torque are in multiples of six and only stator and rotor MMF harmonics with orders of $(6 k \pm 1) P$ can contribute to the ripple torque. On the other hand, the value of $f_{s, v} f_{r, v}$ is amplified by the space harmonic order of $v$. Thus, the highorder space harmonic may contribute disproportionally to the torque ripple amplitude.

Thus, the torque ripple features of the PMaSynRM with different winding topologies can be achieved by evaluating their stator and rotor space MMF harmonics. The PMaSynRM with conventional ISDW is expected to have a higher torque ripple due to their rich harmonics with order of $(6 k \pm 1) P[12][13]$.

\section{Novel 24 slots 10 poles FSDW Topology}

In this paper, the novel 24 slots 10 poles fractional slot distribution winding is applied to the PMaSynRM with arc-shape flux barrier rotor. With this combination, the motor can maintain a considerable reluctance torque contribution and a much lower torque ripple compared with the PMaSynRM with ISDW topology such as 30 slots 10 poles (30S-10P) and 60 slots 10 poles $(60 \mathrm{~S}-10 \mathrm{P})$ or with FSCW such as 12 slots 10 poles (12S-10P) and 18 slots 10 poles (18S-10P). Fig. 1 shows the four PMaSynRMs with different winding topologies or slot pole combinations. More details and comparison with different winding topologies will be presented in the next section. Their slot pitch and winding factor is summarized in TABLE I.

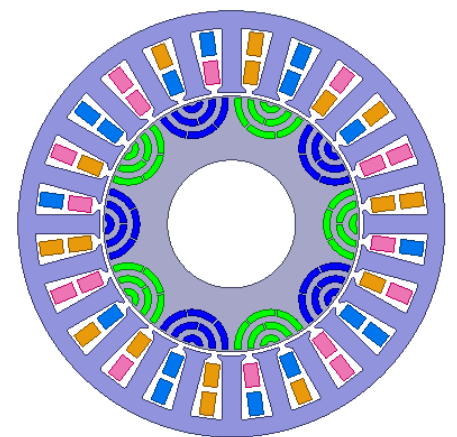

(a) Proposed 24S-10P PMaSynRM $(q=4 / 5)$

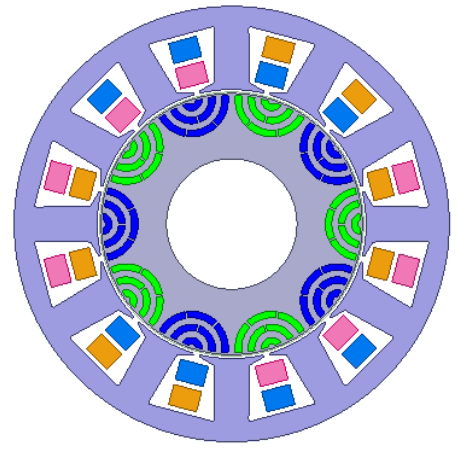

(b) $12 \mathrm{~S}-10 \mathrm{P}$ PMaSynRM $(q=2 / 5)$

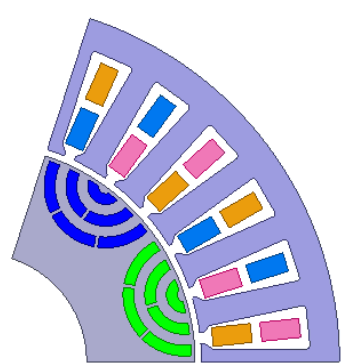

(c) $30 \mathrm{~S}-10 \mathrm{P}(q=1)$

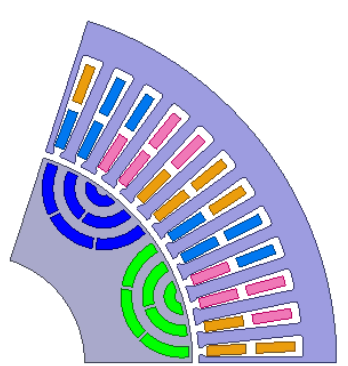

(d) $60 \mathrm{~S}-10 \mathrm{P}(q=2)$
Fig. 1. Four PMaSynRM with different winding topologies.

TABLE I

WINDING CHARACTERISTICS OF DIFFERENT SLOT-POLE COMBINATIONS

\begin{tabular}{c|c|c|c}
\hline Slot-pole & $q$ & Slot pitch & Synchronous winding factor $k_{\mathrm{w}}$ \\
\hline 24S-10P & $4 / 5$ & 2 & 0.925 \\
\hline 12S-10P & $2 / 5$ & 1 & 0.933 \\
\hline 30S-10P & 1 & 2 & 0.866 \\
\hline $60 \mathrm{~S}-10 \mathrm{P}$ & 2 & 5 & 0.933 \\
\hline
\end{tabular}




\section{COMPARATIVE STUDIES}

\section{A. Stator MMF Harmonics}

Based on winding function method [8], the stator space MMF harmonics of these four winding topologies and their FFT spectrum can be plotted, as in Fig. 2. It should be noted that only those harmonics with order of $k^{*} P$ have been plotted, although there are some fractional MMF harmonics for the windings where the $q$ is fractional, viz., $24 \mathrm{~S}-10 \mathrm{P}$ and $12 \mathrm{~S}-10 \mathrm{P}$.

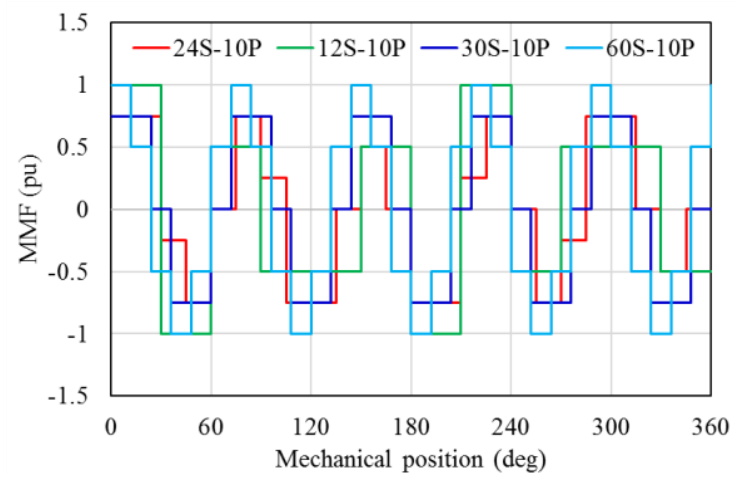

(a) MMF waveform

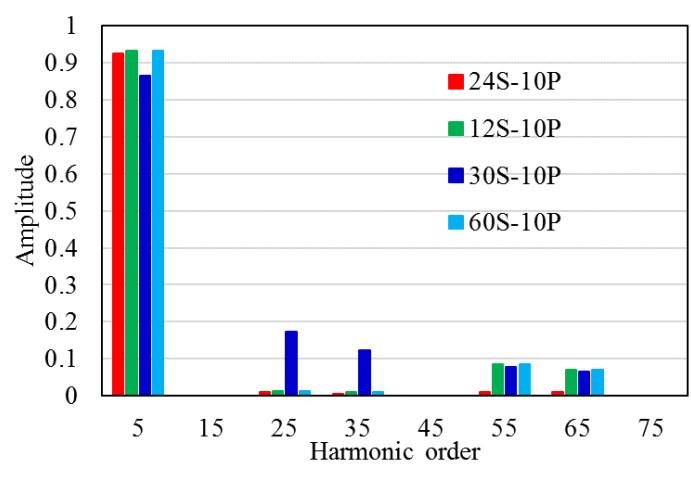

(b) FFT spectrum comparison

Fig. 2. Four PMaSynRM with different winding topologies.

From (12), only MMF harmonics with orders of $(6 k \pm 1) P$ contribute to torque ripple. Thus, both $25^{\text {th }}$ and $35^{\text {th }}$ MMF harmonic contribute to $6^{\text {th }}$ order torque ripple, and both $55^{\text {th }}$ and $65^{\text {th }}$ contribute to the $12^{\text {th }}$ order torque ripple.

As can be seen from Fig. 2, for 24S-10P, all the torqueripple-producing stator MMF harmonics including $25^{\text {th }}$, $35^{\text {th }}, 55^{\text {th }}$ and $65^{\text {th }}$ are significantly reduced. The $12 \mathrm{~S}-10 \mathrm{P}$ features reduced harmonics of $25^{\text {th }}$ and $35^{\text {th }}$ contributing to $6^{\text {th }}$ order torque ripple. The high torque-ripple-producing stator MMF harmonics contributing to $6^{\text {th }}$ and $12^{\text {th }}$ order torque ripple exhibit in the $30 \mathrm{~S}-10 \mathrm{P}$ case. However, for $60 \mathrm{~S}-10 \mathrm{P}$, only the torque-ripple-producing stator MMF harmonics contributing to $12^{\text {th }}$ order torque ripple exhibit.

\section{B. Rotor MMF Harmonics}

Based on field-modulating theory [14], the rotor space MMF harmonics after interacting with the stator teeth can be achieved [15].
For the $24 \mathrm{~S}-10 \mathrm{P}$ motor, the rotor MMF harmonics are $(2 k \pm 1) * 5$ and $24 k \pm 5$. Similarly, all the rotor MMF harmonics can be summarized in TABLE II.

TABLE II

ROTOR MMF HARMONICS FOR DIFFERENT SLOT-POLE COMBINATIONS

\begin{tabular}{l|l|l}
\hline Slot-pole & Harmonics & Harmonics with considerable amplitude \\
\hline \multirow{2}{*}{ 24S-10P } & $(2 \mathrm{k} \pm 1) * 5$ & $5,15,25,35,55,65$ \\
\cline { 2 - 3 } & $24 \mathrm{k} \pm 5$, & $(19,29),(43,53),(67,77)$ \\
\hline \multirow{2}{*}{$12 \mathrm{~S}-10 \mathrm{P}$} & $(2 \mathrm{k} \pm 1) * 5$ & $5,15,25,35,55,65$ \\
\cline { 2 - 3 } & $12 \mathrm{k} \pm 5$, & $(7,17),(19,29),(31,41)$ \\
\hline \multirow{3}{*}{$30 \mathrm{~S}-10 \mathrm{P}$} & $(2 \mathrm{k} \pm 1) * 5$ & $5,15,25,35,55,65$ \\
\cline { 2 - 3 } & $\begin{array}{l}30 \mathrm{k} \pm 5, \\
30 \mathrm{k} \pm 15\end{array}$ & $(25,35),(55,65),(85,95),(45,75)$ \\
\hline \multirow{2}{*}{$60 \mathrm{~S}-10 \mathrm{P}$} & $(2 \mathrm{k} \pm 1) * 5$ & $5,15,25,35,55,65$ \\
\cline { 2 - 3 } & $60 \mathrm{k} \pm 5$, & $(55,65),(115,125),(175,185),(45,75)$ \\
\hline
\end{tabular}

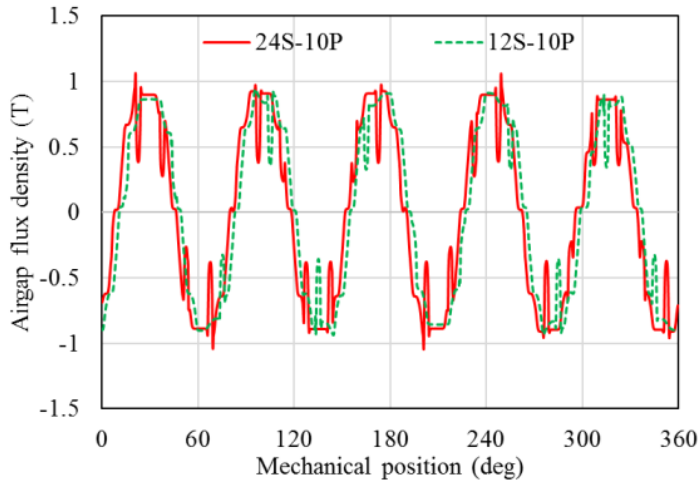

(a) Airgap flux density for $24 \mathrm{~S}-10 \mathrm{P}$ and $12 \mathrm{~S}-10 \mathrm{P}$

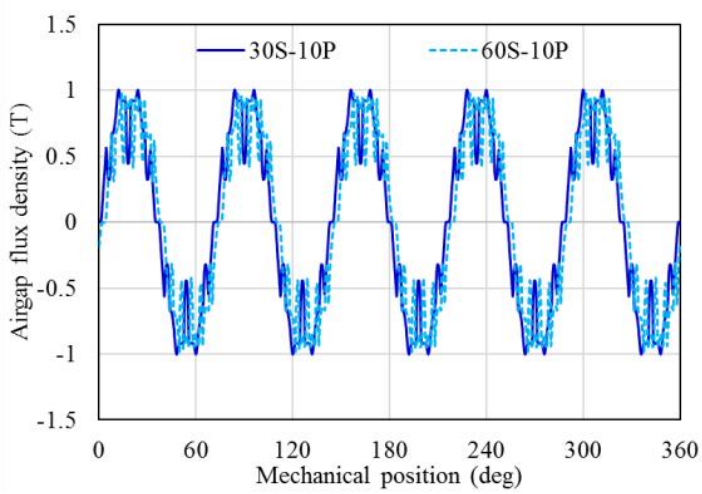

(b) Airgap flux density for 30S-10P and 60S-10P

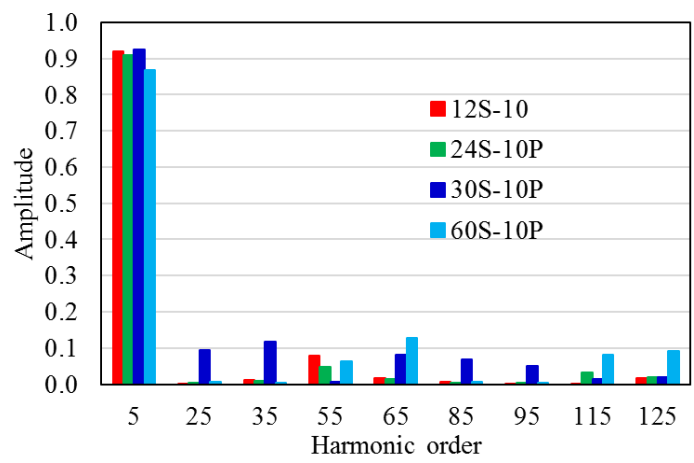

(c) FFT spectrum comparison

Fig. 3. Airgap flux density of the PMaSynRM with different winding topologies. 
Generally, the amplitude of the first or second group of slot harmonics for the rotor fundamental MMF harmonic is considerable. It is worth noting that for the winding configurations where $q$ is fractional, viz., 24S-10P and $12 \mathrm{~S}-10 \mathrm{P}$, the order of those slot harmonics corresponding to the rotor fundamental harmonic do not meet the requirement of $(6 k \pm 1) P$. Hence, although their amplitude is considerable, they do not generate torque ripple from (12).

For the winding configurations where $q$ is integer, viz., $30 \mathrm{~S}-10 \mathrm{P}$ and $60 \mathrm{~S}-10 \mathrm{P}$, the order of those slot harmonics corresponding to the rotor fundamental harmonic meet the requirement of $(6 k \pm 1) P$. Thus, those slot harmonics will generate significant torque ripple due to their considerable amplitude from (12).

Since analytically predicting the rotor MMF harmonic is not the main purpose of this paper, the airgap flux density under no-load condition of these four winding topologies (slot-pole combinations) is simulated as an index of rotor MMF harmonics using an FEA program, as shown in Fig. 3. Again, only those harmonics with order of $k^{*} P$ have been plotted. The impact of stator and rotor MMF harmonics will be discussed in the next section.

\section{Torque Ripple Characteristics}

After analyzing the harmonic distribution of both the stator and rotor MMF harmonics, the relative amplitude of torque-ripple-producing harmonics such as $5^{*} P$ and $7 * P$, $11^{*} P$ and $13^{*} P$ can be observed. Based on the torque ripple expression of (12), the torque ripple characteristics can be evaluated.

As can be seen, for $30 \mathrm{~S}-10 \mathrm{P}$ case, the $25^{\text {th }}$ and $35^{\text {th }}, 55^{\text {th }}$ and $65^{\text {th }}, 85^{\text {th }}$ and $95^{\text {th }}$ harmonic exist in both stator and rotor MMF harmonics. Thus, $6^{\text {th }}, 12^{\text {th }}$, and $18^{\text {th }}$ order torque ripple is expected. For the $60 \mathrm{~S}-10 \mathrm{P}$ case, only $12^{\text {th }}$ and $18^{\text {th }}$ order torque ripple exist as the space harmonics corresponding to $6^{\text {th }}$ torque ripple are eliminated in both stator and rotor MMF.

For the winding configurations where $q$ is fractional, viz., $24 \mathrm{~S}-10 \mathrm{P}$ and $12 \mathrm{~S}-10 \mathrm{P}$, the $25^{\text {th }}$ and $35^{\text {th }}$, and $55^{\text {th }}$ and $65^{\text {th }}$ are considerably reduced at varying extent. Therefore, a lower torque ripple can be expected.

Lastly, among all of them, the proposed 24S-10P PMaSynRM features the lowest torque-ripple-producing space harmonics. Therefore, it has the lowest torque ripple. The FE verification will be presented later.

\section{FE VERIFICATION}

In this section, the EM performance of these four motors will be studied using an FEA program and compared. To make a fair comparison, both the rotor and turns per phase in series are kept the same and only stator numbers are changed. TABLE III summarizes the main geometry of the motor.

\section{A. No-load Performance}

The cogging torque waveform of the four motors is calculated and plotted in Fig. 4. As can be seen, the winding configurations where $q$ is fractional such as $24 \mathrm{~S}$ $10 \mathrm{P}$ and $12 \mathrm{~S}-10 \mathrm{P}$ feature a much lower cogging torque than the ISDW cases such as $30 \mathrm{~S}-10 \mathrm{P}$ and $60 \mathrm{~S}-10 \mathrm{P}$. This is reasonable as the cogging torque is determined by the least common multiplies (LCM) of the slot-pole combination. The higher the LCM, the lower the cogging torque [16].

TABLE III

MAIN GEOMETRY OF THE FOUR PMASYNRMS WITH DIFFERENT WINDING TOPOLOGIES

\begin{tabular}{l|c|l|c}
\hline Parameter & Data & Parameter & Data \\
\hline $\begin{array}{l}\text { Stator outer diameter } \\
(\mathrm{mm})\end{array}$ & 200 & Stator core & JN270-35 \\
\hline $\begin{array}{l}\text { Stator inner diameter } \\
(\mathrm{mm})\end{array}$ & 121.6 & Rotor core & JN270-35 \\
\hline Stack length $(\mathrm{mm})$ & 40 & Magnet material & Sm2Co17 \\
\hline Airgap length $(\mathrm{mm})$ & 0.8 & Peak current $(\mathrm{A})$ & 50 \\
\hline Based speed $(\mathrm{rpm})$ & 1910 & Rated current $(\mathrm{A})$ & 25 \\
\hline
\end{tabular}

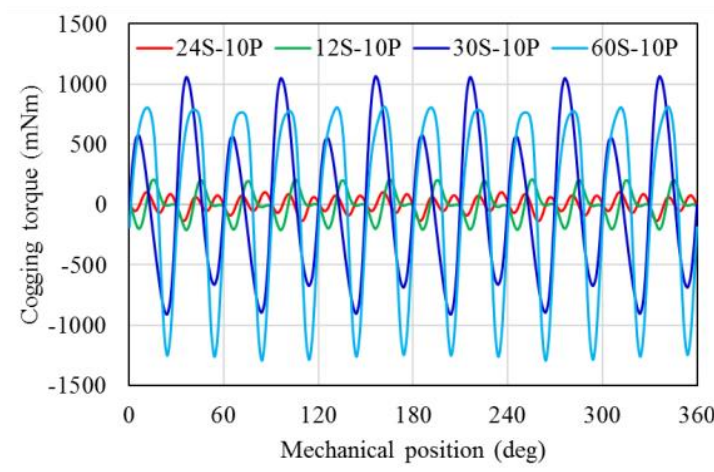

Fig. 4. Comparison of cogging torque.

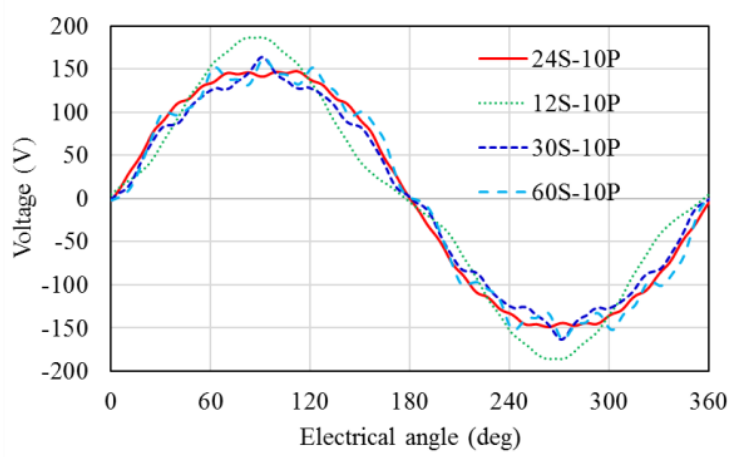

(a) Back EMF waveform

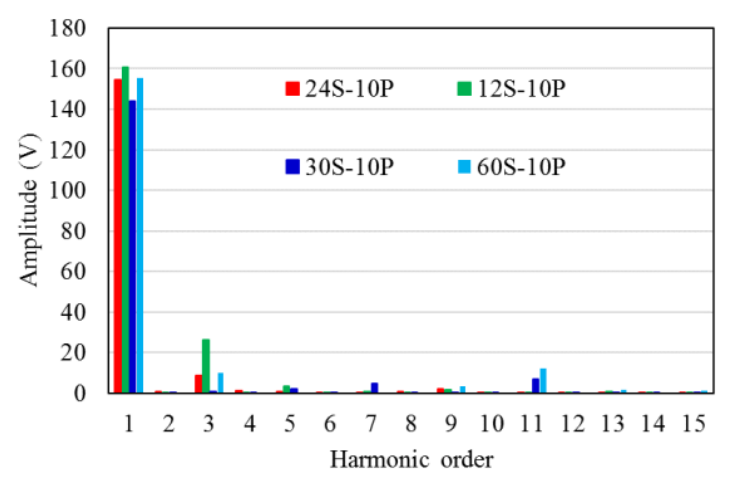

(b) FFT spectrum comparison

Fig. 5. Comparison of no-load back EMF @ 1910 rpm. 


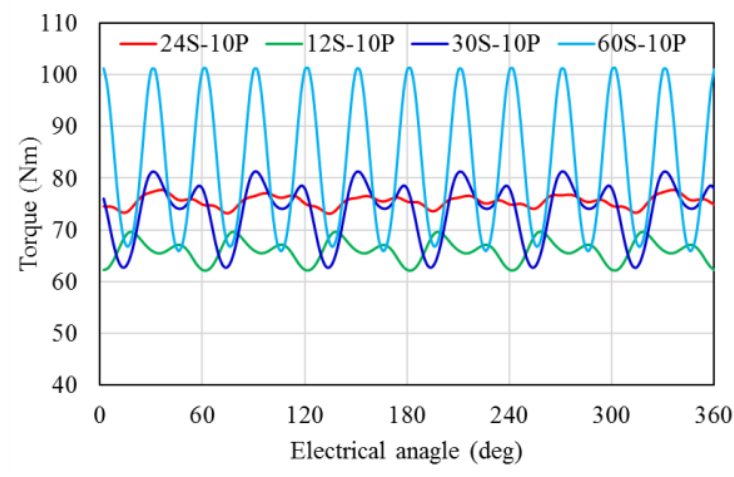

(a) EM torque waveform

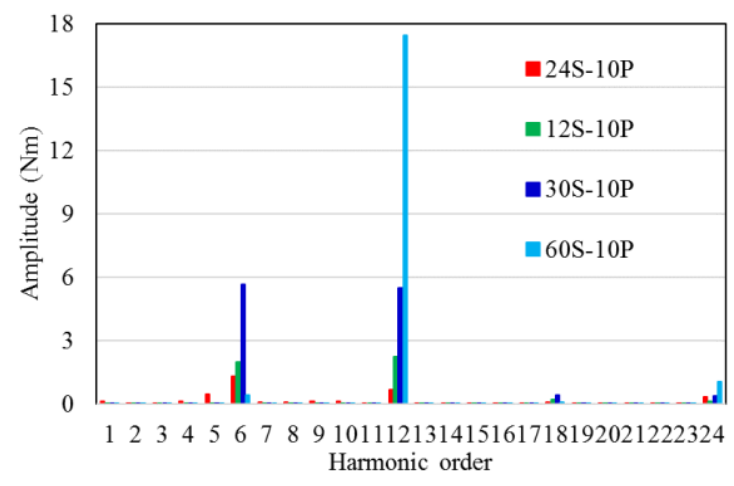

(b) Harmonic distribution of EM torque

Fig. 6. EM torque under MTPA operation with peak current.

The no-load back EMF of the four motors at base speed of 1910rpm is calculated and plotted in Fig. 5. Their back EMF waveform is not purely sinusoidal. An FFT spectrum shows that the relative magnitude of the fundamental EMF harmonic for the four motors is in accordance with their winding factors as developed in TABLE I.

The 24S-10P features minimum harmonic content. The torque-ripple-producing EMF harmonics such as $5^{\text {th }}$ and $7^{\text {th }}$, and $11^{\text {th }}$ and $13^{\text {th }}$ are significantly reduced. The $12 \mathrm{~S}$ $10 \mathrm{P}$ is similar to the $24 \mathrm{~S}-10 \mathrm{P}$ but exhibits a higher $3^{\text {rd }}$ and $5^{\text {th }}$ EMF harmonic. However, the torque-ripple-producing EMF harmonics are rich in both $30 \mathrm{~S}-10 \mathrm{P}$ and $60 \mathrm{~S}-10 \mathrm{P}$. Thus, the lowest torque ripple again is expected for the proposed 24S-10P motor.

\section{B. Load Performance}

The EM torque waveform of the four motors under peak current with maximum torque per ampere (MTPA) operation is plotted in Fig. 6. Their average value and torque ripple are summarized in TABLE IV.

The 12S-10P PMaSynRM has the lowest average torque of $66 \mathrm{Nm}$, which is because of their reduced reluctance torque capability [7]. The proposed 24S-10P PMaSynRM has slightly higher average torque than the $30 \mathrm{~S}-10 \mathrm{P}$, but a lower torque than the $60 \mathrm{~S}-10 \mathrm{P}$.

The lowest torque ripple of $6 \%$ is observed for proposed 24S-10P PMaSynRM. The 12S-10P PMaSynRM has a slightly higher torque ripple of $12 \%$. Much higher torque ripple is seen for both $30 \mathrm{~S}-10 \mathrm{P}$ and $60 \mathrm{~S}-10 \mathrm{P}$. The significant torque ripple for $60 \mathrm{~S}-10 \mathrm{P}$ is due to the fact that the lowest order of its torque ripple harmonic is 12 , and from (12) the high order space harmonic may contribute disproportionally to the torque ripple amplitude.

TABLE IV

EM TORQUE OF THE FOUR PMASYNRMS UNDER MTPA OPERATION WITH PEAK CURRENT

\begin{tabular}{c|c|c|c|c}
\multicolumn{5}{c}{ WITH PEAK CURRENT } \\
\hline $\begin{array}{c}\text { MTPA angle } \\
(\mathrm{deg})\end{array}$ & $24 \mathrm{~S}-10 \mathrm{P}$ & $12 \mathrm{~S}-10 \mathrm{P}$ & $30 \mathrm{~S}-10 \mathrm{P}$ & $60 \mathrm{~S}-10 \mathrm{P}$ \\
\hline $\begin{array}{c}\text { Average } \\
\text { torque (Nm) }\end{array}$ & 75.6 & 65 & 50 & 50 \\
\hline $\begin{array}{c}\text { Peak to peak } \\
\text { torque (Nm) }\end{array}$ & 4.7 & 7.6 & 18.6 & 35.3 \\
\hline $\begin{array}{c}\text { Torque } \\
\text { ripple (\%) }\end{array}$ & 6 & 12 & 25 & 42 \\
\hline
\end{tabular}

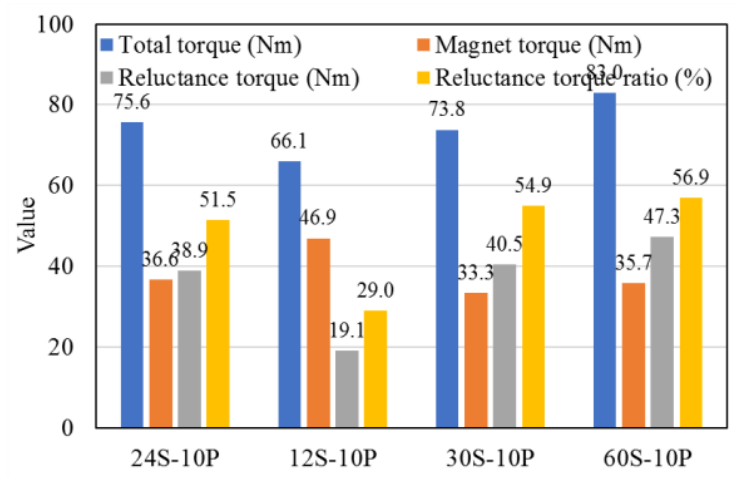

Fig. 7. Torque components under MTPA operation with peak current

Fig. 7 shows the torque components of the four PMaSynRMs under MTPA operation with peak current. The reluctance torque contribution of the proposed $24 \mathrm{~S}$ 10P PMaSynRM is $51.5 \%$ which is very close to the $30 \mathrm{~S}$ $10 \mathrm{P}$ and 60S-10P. For the 12S-10P PMaSynRM, the reluctance torque ratio is very limited, about $29 \%$.

All this confirms that the proposed $24 \mathrm{~S}-10 \mathrm{P}$ features much lower torque ripple while keeping a good reluctance torque capability.

\section{Inductance Analysis}

The inductance value of each component is calculated and summarized in TABLE V, where $L_{0}, M_{0}, L_{2}$, and $M_{2}$ are directly calculated from $\mathrm{FE}$ analysis.

TABLE V

COMPARISON OF INDUCTANCE COMPONENTS

\begin{tabular}{l|c|c|c|c}
\hline & $24 \mathrm{~S}-10 \mathrm{P}$ & $12 \mathrm{~S}-10 \mathrm{P}$ & $30 \mathrm{~S}-10 \mathrm{P}$ & $60 \mathrm{~S}-10 \mathrm{P}$ \\
\hline$L_{0}$ & 6.9 & 9.2 & 4.3 & 5.3 \\
\hline$M_{0}$ & -1.5 & -0.4 & -2.0 & -2.0 \\
\hline$L_{2}$ & -1.7 & -2.8 & -1.2 & -1.5 \\
\hline$M_{2}$ & -1.4 & -0.4 & -1.2 & -1.5 \\
\hline $\begin{array}{l}\text { Mutual inductance } \\
\text { factor }\left(M_{2} / L_{2}\right)\end{array}$ & 0.80 & 0.12 & 1.00 & 1.00 \\
\hline$L_{\mathrm{d}}$ & 6.2 & 7.8 & 4.5 & 5.0 \\
\hline$L_{\mathrm{q}}$ & 10.7 & 11.3 & 8.2 & 9.6 \\
\hline Saliency ratio & 1.7 & 1.5 & 1.8 & 1.9 \\
\hline
\end{tabular}

As can be seen, the conventional $12 \mathrm{~S}-10 \mathrm{P}$ has a negligible mutual inductance between phases while the proposed 24S-10P features a much higher mutual inductance. The mutual inductance ratio comparison shows that the proposed $24 \mathrm{~S}-10 \mathrm{P}$ has a comparable mutual coupling between phases compared to the conventional ISDW cases i.e. 30S-10P and 60S-10P. A comparable saliency ratio compared to conventional ISDW cases is 
also observed in the proposed 24S-10P PMaSynRM.

In addition, this reveals that one of the key ways to improve the reluctance torque is to enhance the mutual coupling between phases; and this is the reason for the improved reluctance torque capability of the proposed 24S-10P PMaSynRM compared to conventional FSCW configurations.

\section{CONCLUSIONS}

This paper presents a 24 slots 10 poles PMaSynRM, which has a fractional slot distributed winding (FSDW). The stator and rotor space MMF characteristics have been presented to reveal the principle of low torque ripple. In addition, the mutual inductance ratio is introduced to reveal the essence of improving reluctance torque capability. Compared to PMaSynRM equipped with the conventional ISDW, the proposed 24 slots 10 poles PMaSynRM has the advantages of much lower cogging torque and torque ripple while keeping a comparable reluctance torque capability. All this demonstrates it could be a good trade-off solution for traction motor application. More studies on the performance such as efficiency and demagnetization characteristics over a wide range speed operation and experimental validation will be reported in future publications.

\section{REFERENCES}

[1] Jurkovic, Sinisa, et al, "Next generation chevy volt electric machines; design, optimization and control for performance and rare-earth mitigation.” 2015 IEEE Energy Conversion Congress and Exposition (ECCE), pp. 5219-5226, 2015.

[2] Dorrell, David G., et al. "Comparison of different motor design drives for hybrid electric vehicles." 2010 IEEE Energy Conversion Congress and Exposition (ECCE), 2010, pp. 3352-3359.

[3] Boldea, I., Tutelea, L.N., Parsa, L. and Dorrell, D., "Automotive electric propulsion systems with reduced or no permanent magnets: An overview." IEEE Trans. Ind. Electron., vol. 61, no.10, pp.5696-5711, 2014.

[4] Zhu, S., Cox, T., Xu, Z. and Gerada, C., "Novel 24-slots14poles fractional-slot concentrated winding topology with low-space harmonics for electrical motor." The Journal of Engineering, 2019(17), pp.3784-3788.

[5] Sarlioglu, B., Morris, C.T., Han, D. and Li, S., "Benchmarking of electric and hybrid vehicle electric motors, power electronics, and batteries." 2015 International Conference on Optimization of Electrical \& Electronic Equipment (OPTIM), pp. 519-526. IEEE, 2015.

[6] Dajaku, G.; Gerling, D., "A Novel 24-Slots/10-Poles Winding Topology for Electric motors." 2011 IEEE International Electric Motors \& Drives Conference (IEMDC), pp.65-70, 2011.

[7] M. Gamba, G. Pellegrino and A. Vagati, "A new PMassisted Synchronous Reluctance machine with a nonconventional fractional slot per pole combination." 2014 International Conference on Optimization of Electrical and Electronic Equipment (OPTIM), pp. 268-275, 2014.

[8] Thomas A. Lipo, Introduction to AC Machine Design. Wiley-IEEE Press, 2018.

[9] Ge, Hao, "Fractional slot concentrated winding interior permanent magnet motors with reluctance torque: inductance-based methodology for comprehensive analysis, design, and control." PhD dissertation, 2016.
[10] Gamba, Matteo, et al, "Synchronous reluctance motor with concentrated windings for IE4 efficiency." 2017 IEEE Energy Conversion Congress and Exposition (ECCE). IEEE, pp. 3905-3912, 2017.

[11] Han, Seok-Hee, Thomas M. Jahns, and Wen L. Soong, "Torque ripple reduction in interior permanent magnet synchronous machines using the principle of mutual harmonics exclusion.” 2007 IEEE Industry Applications Annual Meeting, pp. 558-565, 2007.

[12] L. Alberti, M. Barcaro and N. Bianchi, "Design of a LowTorque-Ripple Fractional-Slot Interior Permanent-Magnet Motor." IEEE Trans. Ind. App., vol. 50, no. 3, pp. 18011808, 2014.

[13] Vagati, Alfredo, et al., "Design of low-torque-ripple synchronous reluctance motors." IEEE Trans. Ind. App., vol. 34, no. 4, pp. 758-765, 1998.

[14] M. Cheng, P. Han and W. Hua, "General Airgap Field Modulation Theory for Electrical Machines." in IEEE IEEE Trans. Ind. Electron., vol. 64, no. 8, pp. 6063-6074, 2017.

[15] N. Bianchi, M. D. Pré, G. Grezzani, and S. Bolognani, "Design considerations on fractional-slot fault-tolerant synchronous motors," IEEE Trans. Ind. Appl., vol. 42, no. 4, pp. 997-1006, 2006.

[16] Bianchi, N. and Bolognani, S., "Design techniques for reducing the cogging torque in surface-mounted PM motors." IEEE Trans. Ind. App., vol. 38, no. 5, pp.1259$1265,2002$. 